rungsebenen als recht unhandlich. Dennoch wird die Völkerrechtswissenschaft bei der Beurteilung der "privaten Gewalt" an diesem Werk in Zukunft nicht vorbeigehen können.

\title{
Oliver Dörr
}

\section{Edward Kwakwa}

\section{The International Law of Armed Conflict: Personal and Material Fields of Application}

Martinus Nijhoff Publishers, Dordrecht, 1992, 208 pp., US\$ 87.50

This book is a revised version of a thesis submitted to the Yale Law Faculty in 1990; the manuscript on which it was based was awarded the 1991 Paul Reuter Prize by the International Committee of the Red Cross.

In his introduction, the author first clarifies the terms "international armed conflict", a euphemism for the less desirable term of "war", and "international humanitarian law" nowadays equivalent to the "law of war" or "armed conflict". He also defines the usage of the "law of Geneva" and the "law of the Hague", explains the purpose of his study and summarizes his arguments and conclusions.

He lists the historical origins of the law of war in his first chapter and then analyses this law in historical perspective in the second, while chapter three scrutinizes problems of international law of armed conflict with special regard to the difficulties which arise when fitting this particular area of international law within the formulation of the international law sources as given in Art. 38 (1) of the Statute of the International Court of Justice. Kwakwa concludes here that some general principles have crystallized through the practice of state and non-state entities.

Chapters four to six are most relevant. The law of armed conflict develops through claims and counter-claims of states and other actors in the international arena. While chapter four discusses claims pertaining to material fields of application - where Kwakwa argues for a rather expansive interpretation of the concepts of "war" and "international armed conflict" in order to include as many conflict situations as possible under the umbrella of the law of war (especially interesting is the issue of national liberation), chapter five deals with claims ratione personae. The author suggests more humanitarian treatment of guerrillas but at the same time believes a strict adherence by the guerrillas to the rules of warfare to be insisted upon.

The topics discussed in chapter six and seven are implementation and enforcement, the question of belligerent reprisals and finally the evaluation of the other available means of enforcing the international law of conflict.

Edwand Kwakwa ends with recommendations for an approach towards a more humanitarian international law of armed conflict. Although various new developments have taken 
place since the author's extensive research documented in the very good bibliography, the reader can still benefit from the well-structured thoughts and opinions on this topic.

Dagmar Reimmann

Richard J. Grunawalt (Ed.)

The Law of Naval Warfare: Targeting Enemy Merchant Shipping

U.S. Naval War College, Newport, Rhode Island, 1993, 383 pp., US\$ 15.00

(International Law Studies 1993, Vol. 65)

\section{J. Ashley Roach / Robert W. Smith}

\section{Excessive Maritime Claims}

U.S. Naval War College, Newport, Rhode Island, 1994, 376 pp.

(International Law Studies 1994, Vol. 66)

In der seit 1901 erscheinenden Reihe der "blue books" des U.S. Naval War College wird unter Gesichtspunkten der Sicherheitspolitik und des Seekriegsrechts ständig zum Seerecht publiziert.

Der Tagungsband von Grunawalt zum Thema "Targeting Enemy Merchant Shipping", also der Versenkung feindlicher Handelsschiffe, faßt die z.T. konträren Statements von 17 Völkerrechtlern und Militärs aus einem seekriegsrechtlichen Symposium vom Februar 1990 zusammen. Dort ergab sich insofern ein Rechtsproblem, als das bis heute fortgeltende Londoner U-Boot-Protokoll von 1936 die warnungslose Versenkung feindlicher Handelsschiffe (von wenigen Ausnahmen abgesehen) verbietet. Kriegsschiffe - auch UBoote - sollen zuvor die Passagiere und Besatzungsmitglieder und die Schiffspapiere "an einen sicheren Ort bringen". Diese humanitäre Regelung zum Schutz ziviler Personen und Objekte ist im Laufe des 2. Weltkrieges wie auch in den nachfolgenden Konflikten im Zeichen bewaffneter Handelsschiffe und totaler, auch wirtschaftlicher Kriegführung von allen Parteien weitgehend ignoriert worden, wobei die Kriegführenden sich erfolgreich auf besondere Rechtfertigungsgründe berufen konnten.

Der verständliche Wunsch zur Stärkung des humanitären Kriegsvölkerrechts einerseits wie andererseits neue waffentechnische Forderungen nach zuverlässiger Unterscheidung ziviler, feindlicher oder neutraler Ziele (z.B. Lazarettschiffe, Küstenfischer) bestimmte die Diskussionen dieses Symposiums. Herausgekommen ist keine neue Patentlösung, aber doch die deutliche Forderung, an der Schutzklausel von 1936 soweit wie möglich festzuhalten und sie der Realität der modernen Konflikte auf See anzupassen. Die hierfür in Frage kommenden seerechtlichen Instrumente können z.B. in der Erklärung von Kampfzonen (wie im Falkland-Krieg) oder in der Erarbeitung von Unterscheidungskriterien und -verfahren (Vorschlag von Marinevertretern) liegen. 